\title{
Influence of Calf Weaning at Birth on Reproductive Performance of Murrah Buffaloes
}

\author{
Ajesh Kumar, M.L. Kamboj, Santosh Kumar, Suresh Chandar Jingar*, \\ R.K. Meena, M.C. Yadav, Pankaj Lawania, H.L. Bugalia and Parsant Jatolia \\ National Dairy Research Institute, Karnal-132 001, Haryana, India \\ *Corresponding author
}

\author{
A B S T R A C T
}

\begin{tabular}{|l}
\hline Ke y w o r d s \\
$\begin{array}{l}\text { Days to first heat, } \\
\text { Service period, Calf } \\
\text { weaning, Buffalo. }\end{array}$ \\
\hline Article Info \\
\hline $\begin{array}{l}\text { Accepted: } \\
\text { 30 September } 2017 \\
\text { Available Online: } \\
\text { 10 November } 2017\end{array}$
\end{tabular}

\section{Keywords}

Days to first heat, Service period, Calf weaning, Buffalo.

Accepted: Available Online:

10 November 2017
The aim of this study was to investigate the effect of buffalo's calf weaning and suckling on reproductive performance of dam. Sixteen down calver Murrah buffaloes were selected and divided into two groups of 8 buffaloes in each group as weaned (T1) and suckling (T2) on the basis of their similarity in lactation milk yield and parities and reproductive performance. The buffaloes from the group of suckling were allowed to suckle colostrum as well as milk however, Weaned group calves were weaned from their dams immediately after birth fed colostrum and milk artificially.Total experimental period was 180 days after calving.The days to first heat (72 vs. 53), days to first service ( 93.50 vs. 75.13 ) and service period (147 vs. 117 days) service per conception $(1.50 \pm 0.19$ and $2.75 \pm 0.39)$ were reported differ significantly $(\mathrm{P}<0.05)$ higher in between suckling $(\mathrm{T} 2)$ in comparison to weaned $(\mathrm{T} 1)$ group of buffaloes. Therefore, present study can be concluded that suckling of buffalo calf elongate days to first heat, days to first service and service period, however, increases the number of service per conception.

\section{Introduction}

Buffaloes are backbone of Indian milk production and are considered difficult to breeders. Several factors affect reproductive performance and being addressed using different bio-technological interventions. Most of buffaloes are reared under traditional management practices by small and marginal farmers in rural area.

Milk is major source of income from buffalo dairy farming obtained by allowing calf to suckle the dam. Thus, allow suckling of dam to let down the milk is practice by large number of farmers (Kamboj and Tomer, 2002). However, suckling in cow have been found to delay the initiation of oestrus cyclicity, thus, increases intervals to first postpartum oestrus and ovulation in comparison to weaned cow (Bellows et al., 1974; Yavas and Walton, 2000). While there is overwhelming evidence to support the effect of weaning in inducing earlier initiation of ovarian activity and return to postpartum oestrus in cattle, however, scanty of literature is available on buffalo in Indian condition.

Therefore, the present study was undertaken to investigate effect of calf suckling and weaning on reproductive performance in postpartum buffaloes. 


\section{Materials and Methods}

The study was conducted on the calves and their dams in Murrah buffaloes herd maintained at the National Dairy Research Institute (NDRI), Karnal (Haryana). The NDRI, Karnal is situated on an altitude of 250 meters, above mean sea level, latitude and longitude position being $29^{\circ} 42^{\prime \prime} \mathrm{N}$ and $77^{\circ} 54^{\prime \prime}$ $\mathrm{E}$ respectively. The maximum ambient temperature in summer goes up to $45^{\circ} \mathrm{C}$ and absolute minimum temperature falls to around $4^{\circ} \mathrm{C}$ in winter during the experimental period. The average annual rainfall is about $700 \mathrm{~mm}$, most of which is received from early July to mid-September with occasional winter showers in the months of December and January. To compare the effect of suckling and weaning of calf 16 down calver buffaloes and their calves were selected from the Murrah buffalo herd maintained at the institute. All the selected buffaloes were in their first to fifth lactation. The selected buffaloes were divided into two groups comprising 8 buffaloes in each group named as weaned (T1) and suckled (T2) group on the basis of similar lactation milk yield (1737.00 vs. $1736.5 \mathrm{~kg}$ ) and parities (1.75 vs. 1.62$)$ respectively. The buffaloes from the group of suckling were allowed natural suckling of colostrum as well as milk and for let-down of milk (Twice in a day). In the weaned group calves were weaned from their dams immediately after birth. The selected buffaloes were hand milked by twice daily at 5.00 AM in the morning and 6:30 PM in the evening. Buffaloes were maintained under loose housing system at institute cattle yard during whole experimental period. Both, Suckled and weaned groups of buffaloes caves was kept in calves shed separately. All the experimental buffaloes were offered green fodder ad libitum in their paddock and concentrate feeding was done during milking in the byre. Various reproductive parameters were monitored from calving to day 180 postpartum.The reproductive parameters was done by personal observation and by parading of a teaser bull in the buffalo sheds twice in a day during early morning and at evening. Animals in oestrus were artificial inseminated using the semen of genetically superior bulls available at Institute. Pregnancy was confirmed by per-rectal examination at 60 days post-insemination.

\section{Data analysis}

The data obtained in the study were subjected to the statistical analysis as per procedure described by the Snedecor and Cochran (1994). The significance of the differences between the mean values of various parameters studies was tested by employing Z test through SYSTAT 12.0 (SPSS Inc. Chicago, IL, USA).

\section{Results and Discussion}

Reproduction is closely related to milk production. Prolong days to first heat, length of estrus cycle, days to first service, service period and number of service per conception are not a desirable character in buffalo cow (Madan, 1988). Results observed in present study shown in table 1 and revealed that the mean days to first heat, length of estrus cycle, days to first service, service period and number of service per conception in the weaned (T1) and suckled group (T2) were $53.13 \pm 3.42$ and $72.63 \pm 4.31$ days, $22.99 \pm 0.55$ and $21.10 \pm 1.10$ days, $75.13 \pm 3.41$ and $93.50 \pm 4.11$ days, $117.63 \pm 4.52$ and $147.38 \pm 4.33$ days and $1.50 \pm 0.19$ and $2.75 \pm 0.39$ respectively. The mean of days to first heat, days to first service, service period and number of service per conception were found to be significantly $(\mathrm{P}<0.05)$ lower in weaned group of buffaloes as compared to calf suckled group of buffaloes. Significantly $(\mathrm{P}<0.05)$ higher conception rate $(100.0 \%)$ was recorded in weaned buffaloes than Suckled buffaloes $(62.5 \%)$ within day 150 postpartum while no significant difference found between both groups within day 90 postpartum. 
The postpartum interval to resumption of behavioral estrus was shorter for weaned group of buffaloes than suckled group of buffaloes. Buffaloes of weaned group (T1) showed first estrus around 19 and 20 days prior to the buffaloes of suckled group (T2). The result of present study was in according to previous works. Shortening the periods from calving to first estrus \& conception and improved conception rate in weaned buffaloes has also been reported by Perera, 2011; Thu and Trach, 2012 and Rijasnaz et al., 2014.
Longer postpartum estrus and service period and lower conception rate might be affected by suckling of calf. Longer postpartum estrus and service period and lower conception rate has also been reported by Qureshi and Ahmad (2008); Perera, (2011); Thu and Trach (2012) and Rijasnaz et al., (2014) under suckling system of calf rearing. Jainudeen, (1988) also concluded that suckling is one of the major causes for long inter-calving period in dairy buffaloes whereas weaning reduced the incidence of post-partum anestrous.

Table.1 Mean \pm SE of reproductive performance in Murrah buffaloes

\begin{tabular}{|l|l|l|}
\hline Reproductive parameters & T1 (Weaned, $\mathbf{n = 8})$ & T2 (Suckled, n=8) \\
\hline Number of animal showing estrus up to 90 days of calving & \multicolumn{1}{|c|}{8} & \multicolumn{1}{|c|}{8} \\
\hline Days to first Heat & $53.13 \pm 3.42^{\mathrm{a}}$ & $72.63 \pm 4.31^{\mathrm{b}}$ \\
\hline Length of estrus cycle (days) & $22.99 \pm 2.55$ & $21.10 \pm 1.10$ \\
\hline Days to first service & $75.13 \pm 3.41^{\mathrm{a}}$ & $93.50 \pm 4.11^{\mathrm{b}}$ \\
\hline Service period (days) & $117.63 \pm 4.52^{\mathrm{a}}$ & $147.38 \pm 4.33^{\mathrm{b}}$ \\
\hline Number of services per conception & $1.50 \pm 0.19^{\mathrm{a}}$ & $2.75 \pm 0.39^{\mathrm{b}}$ \\
\hline Proportion of animals (\%) & & \\
\hline First behavioural oestrus before $\quad$ & \\
\hline 1) day 40 postpartum & & $0.0^{\mathrm{b}}$ \\
\hline 2) day 90 postpartum & $12.5^{\mathrm{a}}$ & $100^{\mathrm{b}}$ \\
\hline Conceiving before & $87.5^{\mathrm{a}}$ & \\
\hline 1) day 90 postpartum & & $0.0^{\mathrm{b}}$ \\
\hline 2) day 150 postpartum & $0.0^{\mathrm{b}}$ & $62.5^{\mathrm{b}}$ \\
\hline
\end{tabular}

$a-b$ : Means bearing different superscript differ significantly $(P<0.05)$.

It has been hypothesized that suckling and milk yield can affect activity of the hypothalamus, hypophysis and ovaries, inhibiting follicular development and extending the anestrous period (Lamb et al., 1997). The amount of milk produced during the postpartum period can affect the interval from calving to ovulation. Suckling reduces the hypothalamic release of GnRH, which results in insufficient pulsatile LH release (Williams, 1990). Inhibition of pulsatile LH secretion during lactation and the corresponding increase in pulsatile $\mathrm{LH}$ secretion 2-6 days after removal of the suckling stimulus is well established (Walters et al., 1982; Smith et al., 1983; Williams et al., 1987).

Based on the result observed, the present study concluded that practice of natural suckling prolonged days to first heat, day to conception and decreases the conception rate.

Therefore, weaning may be helpful to improve reproductive efficiency in Murrah buffalo.

\section{Acknowledgements}

The authors are thankful to the Director, National Dairy Research Institute, Karnal and 
Head, Livestock Production and Management for providing necessary facilities and logistic support to conduct the study. Financial support provided by Indian Council of Agricultural Research is duly acknowledged.

\section{References}

Bellows, R. A., Short, R. E., Urick, J. J. and Pahnish, O. F. 1974. Effects of early weaning on postpartum reproduction of the dam and growth of calves born a multiples or singles. Journal of Animal Science, 39: 589.

Jainudeen, M.R., 1988. Reproduction problems of buffaloes in the world. Proceedings of the IIWorld Buffalo Congress, Vol. II, New Delhi, India, pp. 189-196.

Kamboj, M.L., and O.S. Tomer. 2002. Feeding management practices of calves of Nagori cattle under field conditions $10^{\text {th }}$ International Congress of AsianAustralian Association of Animal Production Societies (AAAP). Sept. 23-27, 2002. New Delhi, India.

Lamb, G. C., Lynch, J. M., Greiger, D. M., Minton, J. E. and Stevenson, J. S. 1997. Ad libitum suckling by unrelated calf in the presence or absence of a cow's own calf prolongs postpartum anovulation. Journal of Animal Science, 75: 2762.

Perera, B.M.A.O., 2011. Reproductive cycles of buffalo. Anim. Reprod. Sci., 124: 194-199.

Qureshi, M.S., and Ahmad, N. 2008. Interaction of calf suckling, use of oxytocin and milk yield with reproductive performance of dairy buffaloes. Anim. Reprod. Sci., 106: 380-392.

Rijasnaz, V.V., Mondal S.K. and Fahim A. 2014. Effect of weaning on the postpartum reproductive performance of murrah buffaloes. Indian J. Anim. Res., 48 (5): 501503.

Smith, M. F., Lishman, A., Lewis, G., Harms, P., Ellersick, M., Inskeep, E., Wiltbank, J. and Amos, M. 1983. Pituitary and ovarian responses to gonadotropin releasing hormone, calf removal and progestrogen in anestrous beef cows. Journal of Animal Science, 57: 418-424.

Snedécor, G. W., and Cochran, W. G. 1994. Statistical methods. $7^{\text {th }}$ Edn, Iowa State University Press. Iowa.

Thu Cu Thi Thien and Trach N X. 2012. Effects of early weaning on postpartum resumption of reproduction in mother buffaloes and growth of their calves. Livestock Research for Rural Development 24 (1) downloaded from http://www.lrrd.org//rrd24/1/cont2401.htm

Walters, D. L., Kaltenbach, C. C., Dunn, T. G. and Short, R. E. 1982. Pituitary and ovarian function in postpartum beef cows. I. effects of suckling on serum and follicular fluid hormones and follicular gonadotropin receptors. Biology Reproduction, 26: 640646.

Williams, G. L., 1990. Suckling as a regulator of post-partum rebreeding in. cattle: A review. Journal of Animal Science, 68: 831-52.

Williams, G. L., Kosiorowski, M., Osbom, R. G., Kirsch, J. D. and Slanger, W. D. 1987. The post-weaning rise of tonic luteinizing hormone secretion in anestrous cows is not prevented by chronic milking or the physical presence of the calf. Biology Reproduction, 36:1079.

Yavas, Y., and Walton, J. S. 2000. Postpartum acyclicity in suckled beef cows: A review. Theriogenology, 54:25-55.

\section{How to cite this article:}

Ajesh Kumar, M.L. Kamboj, Santosh Kumar, Suresh Chandar Jingar, R.K. Meena, M.C. Yadav, Pankaj Lawania, H.L. Bugalia and Parsant Jatolia. 2017. Influence of Calf Weaning at Birth on Reproductive Performance of Murrah Buffaloes. Int.J.Curr.Microbiol.App.Sci. 6(11): 4238-4241. doi: https://doi.org/10.20546/ijcmas.2017.611.497 